Article

\title{
Mo and Ni Removal from Drinking Water Using Zeolitic Tuff from Jordan
}

\author{
Khalil M. Ibrahim ${ }^{1, *}$, Hani N. Khoury ${ }^{2}$ and Randa Tuffaha ${ }^{3}$ \\ 1 Department of Earth \& Environmental Sciences, Hashemite University, Zarqa 13133, Jordan \\ 2 Department of Applied Geology, The University of Jordan, Amman 11942, Jordan; \\ khouryhn@ju.edu.jo \\ 3 Laboratories and Quality Affairs/Water Authority of Jordan, Amman 11181, Jordan; \\ randatuffaha@yahoo.com \\ * Correspondence: ibrahm@hu.edu.jo; Tel.: +962-79-558-6042
}

Academic Editor: Javier Sánchez-España

Received: 30 May 2016; Accepted: 8 September 2016; Published: 2 November 2016

\begin{abstract}
Mo and Ni metals could be hazardous in natural waters. The initial Mo and Ni concentration in the sampled domestic drinking water of north Jordan is 550 and $110 \mu \mathrm{g} / \mathrm{L}$, respectively. The efficiency of using natural faujasite-phillipsite and phillipsite-chabazite tuffs in removing Mo and Ni from contaminated drinking water was tested. Batch experiments using different weights of the adsorbent were conducted at different contact times to determine the optimum conditions. The maximal uptake capacity of Mo from drinking water was equivalent to $440-420 \mu \mathrm{g} / \mathrm{g}$ adsorbent. The maximum removal efficiency of Mo by faujasite-phillipsite, phillipsite-chabazite, and the modified surfactant phillipsite-chabazite tuffs were $80 \%, 76 \%$, and $78 \%$, respectively. The proportional relationship between contact time and removal efficiency of $\mathrm{Ni}$ from water samples was observed. The maximum removal efficiency of $\mathrm{Ni}$ by the zeolitic tuffs is up to $90 \%$ compared to the original groundwater sample.
\end{abstract}

Keywords: Mo; Ni; zeolite; faujasite; water treatment; groundwater

\section{Introduction}

The average Mo concentration in the earth's crust is very low $(1.2 \mathrm{mg} / \mathrm{kg})$ [1] and is uniform in common igneous rocks [2]. Mo concentration in igneous rocks and shale with poor organic matter content is the same, whereas it is greatly enriched, up to more than $100 \mathrm{mg} / \mathrm{kg}$, in carbonaceous and pyritic shale (black shale) [3]. Mo substitutes for ferric iron, titanium, aluminum, and possibly silicon in rock-forming minerals [3]. Mo is an essential element in animal and plant nutrition and is ubiquitous in food and water as soluble molybdates [4]. It is involved in forming cofactors in more than 60 enzymes in biology [5]. Humans need $25 \mu \mathrm{g} \cdot$ day $^{-1}$ Mo [6]. Therefore both deficiencies and an excess of Mo in the environment could cause health problems. The Mo cycle, however, is given considerable attention by health organizations.

Mo incorporation and precipitation is highly dependent on $\mathrm{pH}$ and Eh conditions; therefore, Mo migration during weathering is hard to predict $[7,8]$. Mo is a redox-sensitive metal that occurs in low but measurable abundance in aquifers [9]. It forms molybdate oxyanions $\left(\mathrm{HMoO}_{4}{ }^{-1}\right)$ and $\left(\mathrm{MoO}_{4}{ }^{2-}\right)$ in natural water at a $\mathrm{pH}$ range of (2-5) and above 5, respectively [10]. The anionic Mo species are adsorbed by $\mathrm{Fe}, \mathrm{Al}$, and $\mathrm{Mn}$ oxyhydroxides but not strongly adsorbed by clay particles [9]. The molybdate oxyanions, along with other cations such as $\mathrm{Pb}^{2+}, \mathrm{Cu}^{2+}, \mathrm{Zn}^{2+}, \mathrm{Mn}^{2+}$, and $\mathrm{Ca}^{2+}$, coprecipitate with organic matter and calcite $\left(\mathrm{CaCO}_{3}\right)$.

According to Mielke [1], the crustal abundance of $\mathrm{Ni}$ is $99 \mathrm{mg} / \mathrm{kg}$. It varies between $130 \mathrm{mg} / \mathrm{kg}$ in basaltic rocks and $4.5-15 \mathrm{mg} / \mathrm{kg}$ in granitic rocks. This concentration of $\mathrm{Ni}$ igneous rocks correlates 
with those of $\mathrm{Cr}$ and $\mathrm{Co}$ [2]. Ni concentrated in shale is up to $90 \mathrm{mg} / \mathrm{kg}$ relative to carbonates $(<5 \mathrm{mg} / \mathrm{kg}$ ) [1]. Organic matter can contain excess Ni concentrations up to $50 \mathrm{mg} / \mathrm{kg}$. In weathering environment, $\mathrm{Ni}^{2+}$ may occur at low $\mathrm{pH}$, sorbed by clay minerals [11] or hydrous Fe- or Mn-oxides [12]. In natural water, $\mathrm{Ni}$ may exist in one of three oxidation states $(+2,+3$, and +4$)$, although the free ion $\mathrm{Ni}^{2+}$ predominates because it is highly mobile under acidic, oxidizing conditions. Ni is an essential mineral for life [13]. The World Health Organization recommends a daily intake $<20 \mu \mathrm{g} / \mathrm{day}$ for humans [14].

The Wadi Al Arab Well Field (WAWF) is an urban water supply for Irbid District in northern Jordan (Figure 1). The groundwater in the WAWF is contaminated by heavy metals as a result of high concentrations of Mo and other elements such as Cd, Zn, Cu, U, Cr, V, and Ni [15-17]. Action must be taken to mitigate groundwater resources from contamination in order to safeguard the water quality in the WAWF.

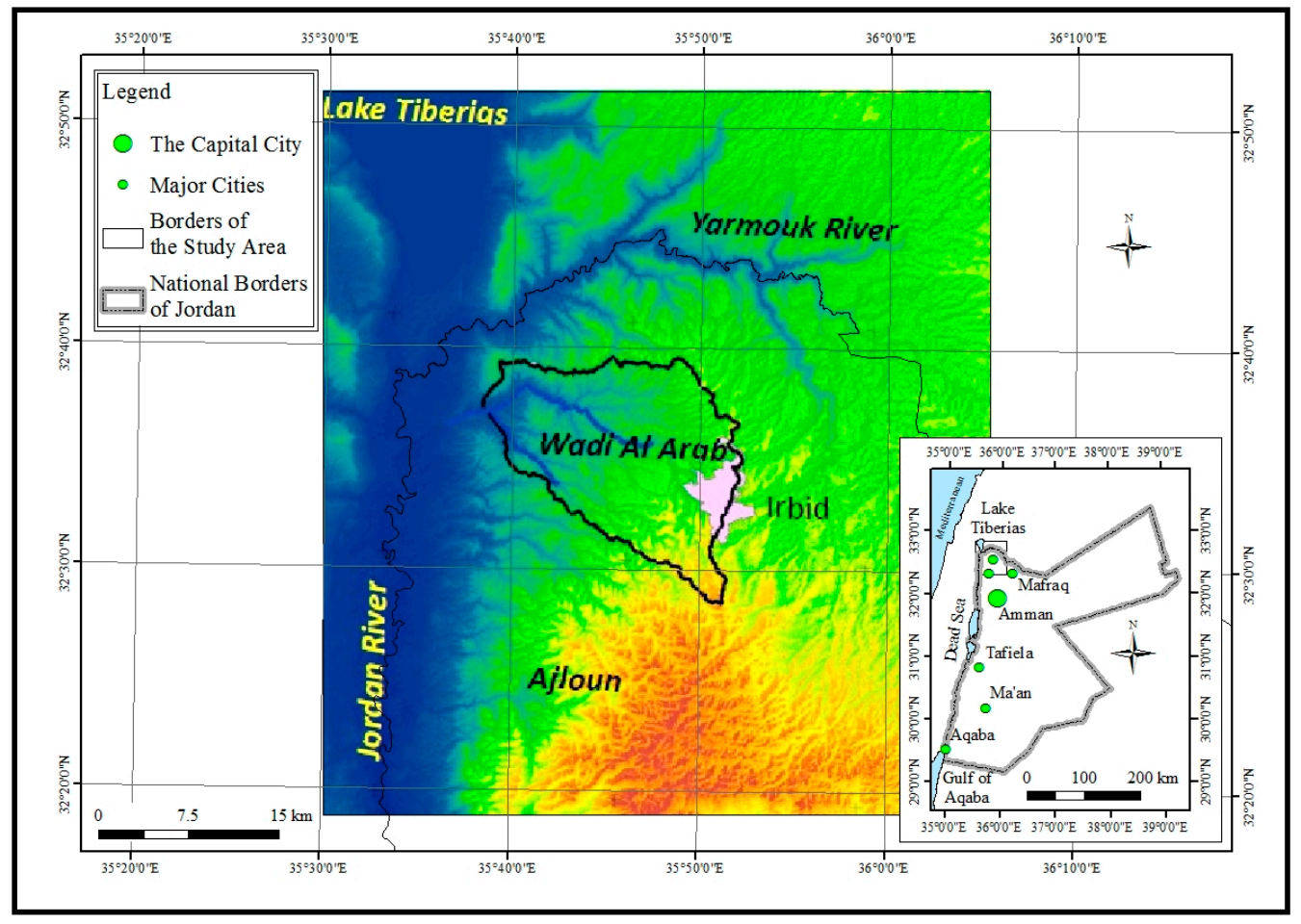

Figure 1. Location map of Wadi Al Arab Well Field [15].

Natural zeolites are important inorganic ion exchangers and adsorbents [18]. Modified forms of natural zeolites are low-cost available resources. They are friendly to the environment with good mechanical and thermal properties, high sorption capacity, and the ability to adjust the $\mathrm{pH}$ of the aqueous system [18]. The surfactant modified zeolites (SMZ) are a form of zeolite that combines the enhanced cation sorption properties of natural zeolites with the ability to sorb anionic species, non-polar organic species, and pathogens from aqueous streams [19]. Surfactant modification usually alters the chemistry of the zeolites surface, allowing the zeolites to sorb nonpolar organic solutes and anions, for which untreated zeolites have little affinity. The Jordanian natural zeolitic tuffs have proved to have excellent sorption behavior to remove heavy metals, ammonium, and organic pollutants from polluted water [20-25]. Ni and the other heavy metals tend to accumulate in organisms, causing numerous diseases and disorders. The use of natural zeolites as potential sorbents for the removal of the heavy metals, including $\mathrm{Ni}$ from industrial wastewater, has been emphasized [20,26-28]. The following work aims at investigating the possibility of using Jordanian zeolitic tuffs as a sink to remove Mo and Ni from contaminated drinking water supplies of the WAWF. 


\section{Materials}

Two representative bulk samples were collected from the Tall Mufteya (TM) and Jabal Hannoun (HN) Quaternary zeolitic tuff [20]. The samples were dry sieved after crushing and grinding to liberate and concentrate zeolites. The highest zeolite concentration was obtained from sieves (1-0.3 mm). The (HN) sample was previously characterized and is mainly composed of faujasite-phillipsite $[20,23]$. The (TM) sample was characterized in this work.

A PerkinElmer Atomic Absorption Spectrometer (AAS) (PerkinElmer, Houston, TX, USA) was used to analyze for the major oxides of the studied samples. A representative portion of each sample was digested inside a Teflon beaker embedded inside a steel bomb using hydrofluoric acid and Aqua-regia for the AAS analysis. Cation exchange capacity (CEC) and anionic exchange capacity (AEC) were determined by using the Kjeldahl method, as described by Kitsopoulos [29]. Specific surface area and pore size distributions were estimated through Brunauer-Emmett-Teller modeling (BET) using a nitrogen adsorption/desorption instrument (Nova 2200e, Quantachrome Instruments, Boyton Beach, FL, USA). The TM sample was modified by using hexadecyltrimethylammonium bromide (HDTMA-Br) at 100\% following the method of Li and others [30] by mixing about $30 \mathrm{~g}$ of the TM sample with $90 \mathrm{~mL}$ of $50 \mathrm{mmol} / \mathrm{L}$ of HDTMA-Br to obtain 100\% of its ECEC. The zeolite mixture was shaken for $8 \mathrm{~h}$ at $25^{\circ} \mathrm{C}$ and $150 \mathrm{rpm}$ on a thermostatic shaker, followed by centrifuging and washing with distilled water. The surfactant-modified samples were then air dried prior to further use.

The morphological features of the zeolitic samples were obtained by using a Pan Analytica INSPECT F50 (FEI, Hillsboro, OR, USA) scanning electron microscope (SEM). The samples were mounted on aluminum stubs by using double-sided sticky conductive carbon, and were coated at $1200 \mathrm{~V}, 20 \mathrm{~mA}$ with platinum.

Drinking water samples were collected from four working wells from the WAWF. A 200-L sample was collected from Well No. 5 during a second sampling campaign. The pH, Eh, EC, turbidity, and temperature for each sample were measured in situ. Analysis of Mo in the original and the treated water samples was carried out using an ICP-MS model Optima PerkinElmer-3000 (Waltham, MA, USA). Water analyses were carried out following the standard methods for the examination of water and wastewater by Rice and others [31].

Batch experiments were conducted to verify the efficiency of the TM and HN samples. The effect of contact time on $\mathrm{Mo}$ and $\mathrm{Ni}$ adsorption was investigated. One gram of the ion exchanger/adsorbent (surfactant modified TM, non-modified TN, and non-modified HN) was added into an Erlenmeyer flask with $20 \mathrm{~mL}$ of groundwater sample. The flask with the sample and the groundwater was subjected to continuous shaking in a water bath at room temperature and $150 \mathrm{rpm}$. This experiment was repeated by changing different contact time and ion exchanger weight (1-3 g) and groundwater volume $(20-200 \mathrm{~mL})$.

\section{Results}

\subsection{Characterization of the Zeolitic Tuff}

The size fraction (1-0.3 $\mathrm{mm}$ ) forms $42 \%$ by weight of the original sample with the highest zeolite wt $\%$ (55\% and 65\% in TM and the HN samples, respectively) compared with the total zeolite content in the original samples, which varies between 35\% and 40\%. The XRD results of the TM sample have indicated the presence of about $30 \%$ phillipsite and $25 \%$ chabazite. Other non-zeolite minerals include olivine, pyroxene, plagioclase, and palagonite, along with traces of smectite and calcite. The scanning electron micrographs of the TM sample emphasized the presence of phillipsite and chabazite as aggregates ranging in size from 600 to $100 \mu \mathrm{m}$ (Figure 2). Phillipsite crystals appear as radial aggregates (Figure 2A,B), while chabazite rhombohedral crystals with penetration twinning appear as clusters (Figure 2C,D). Chemical analysis of phillipsite crystals by the SEM-EDX shows that phillipsite comprises variable amounts of $\mathrm{Na}, \mathrm{K}$, and $\mathrm{Ca}$ in the molecular structure. $\mathrm{K}$ represents 
the highest cation (Figure 3a). Meanwhile, chabazite crystals are distinguished by the high $\mathrm{Mg}$ content (Figure 3b).
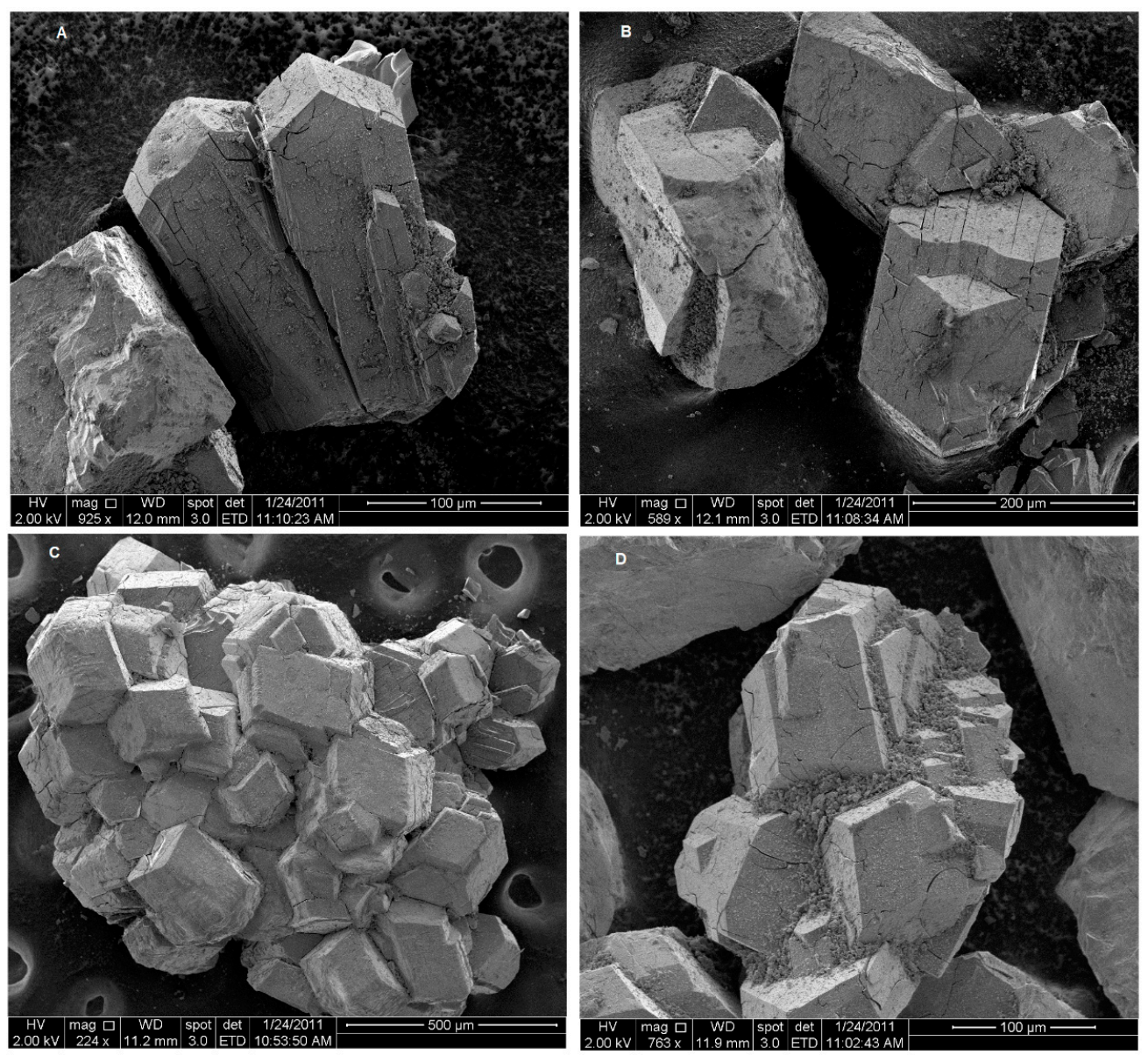

Figure 2. Scanning electron micrographs showing: (A,B) radial aggregates of phillipsite; $(C, D)$ rhombohedral chabazite crystal aggregates with penetration twinning.
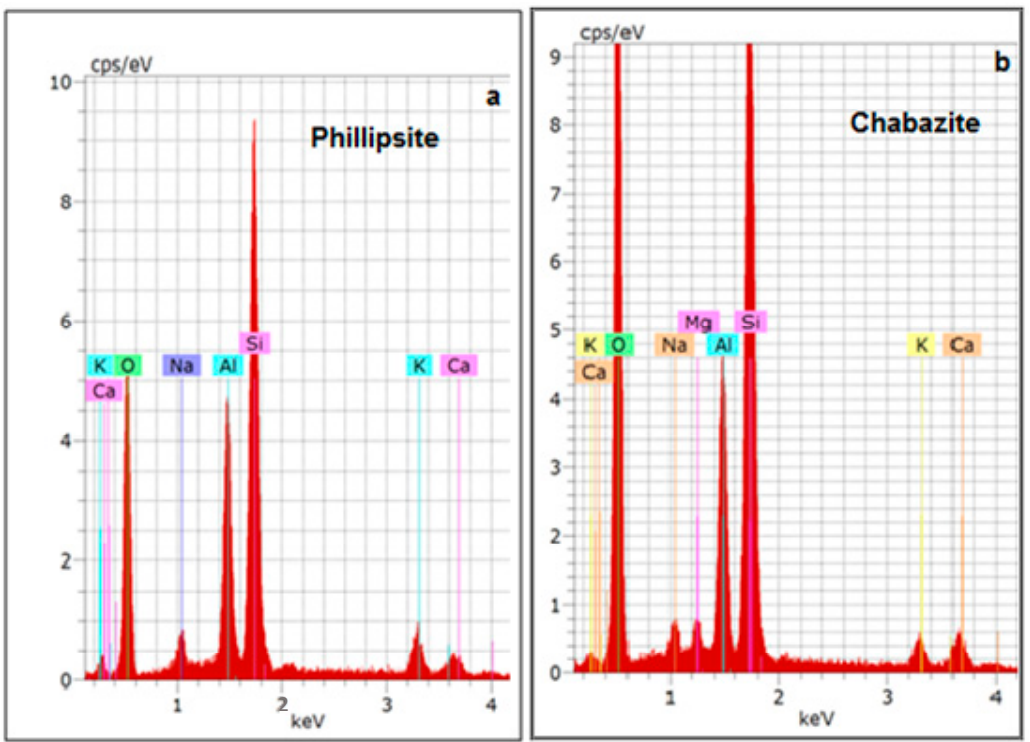

Figure 3. Energy dispersive X-ray spectra: (a) Na-, K-, Ca-phillipsite and (b) Na-, Mg-, K-, Ca-chabazite crystals. 
Table 1 shows a comparison between the chemical composition of the TM and HN samples. The specific surface area (SSA) and cation exchange capacity (CEC) values for the TM sample are equal to $60.32 \mathrm{~m}^{2} / \mathrm{g}$ and $180 \mathrm{meq} / 100 \mathrm{~g}$, respectively (Table 1). The SSA value of the TM sample is close to the upper limit of SSA range 33.4-65.5 $\mathrm{m}^{2} / \mathrm{g}$ of South African natural zeolites [32]. The similarity of the SSA between the studied samples compared with the other natural zeolite indicates their suitability to be used as natural adsorbents. However, common industrial adsorbents like activated carbon have an SSA in the range of 500-2000 $\mathrm{m}^{2} / \mathrm{g}$, with polymeric adsorbents having 150-1000 $\mathrm{m}^{2} / \mathrm{g}$ [32].

Table 1. Chemical composition and other parameters of the studied zeolitic tuff.

\begin{tabular}{|c|c|c|}
\hline Chemical Analysis (wt \%) & Tall Mufteya (TM) & Jabal Hannoun (HN) ${ }^{(1)}$ \\
\hline $\mathrm{SiO}_{2}(\mathrm{wt} \%)$ & 38.49 & 40.05 \\
\hline $\mathrm{TiO}_{2}$ & 0.90 & 2.61 \\
\hline $\mathrm{Al}_{2} \mathrm{O}_{3}$ & 14.43 & 16.23 \\
\hline $\mathrm{Fe}_{2} \mathrm{O}_{3}$ & 11.00 & 8.30 \\
\hline $\mathrm{MgO}$ & 7.76 & 6.70 \\
\hline $\mathrm{CaO}$ & 10.35 & 4.45 \\
\hline $\mathrm{Na}_{2} \mathrm{O}$ & 2.42 & 3.84 \\
\hline $\mathrm{K}_{2} \mathrm{O}$ & 1.73 & 2.77 \\
\hline LOI & 12.41 & 14.50 \\
\hline Total & 99.49 & 99.45 \\
\hline Grain size $(\mathrm{mm})$ & $1-0.3 \mathrm{~mm}$ & $1-0.3 \mathrm{~mm}$ \\
\hline Surface area $\left.\left(\mathrm{m}^{2}\right) / \mathrm{g}\right)$ & 60.32 & $87.61^{(2)}$ \\
\hline CEC (meq/100 g) & 180 & 154 \\
\hline $\mathrm{AEC}(\mathrm{meq} / 100 \mathrm{~g})$ & 121 & \\
\hline \multicolumn{3}{|l|}{ Mineralogy } \\
\hline Zeolite minerals & phillipsite, chabazite & faujasite, phillipsite \\
\hline Zeolite grade (wt \%) & 55 & $65^{(3)}$ \\
\hline
\end{tabular}

The CEC values in the TM and HN samples as given in Table 1 are higher than the South African natural zeolites [32] and similar to zeolitic tuff from other localities from Jordan [20]. It is important to note that the CEC value is usually related to zeolite percentage in the sample and to zeolite mineral type.

\subsection{Characterization of the Water Samples}

Table 2 shows that Mo concentrations in the four sampled productive wells in the WAWF range between 330 and $790 \mu \mathrm{g} / \mathrm{L}$. The WHO has recommended since 1993 a health-based guideline value $(70 \mu \mathrm{g} / \mathrm{L})$ for Mo in drinking water [6]. In the USA, Wisconsin has set a health-based groundwater standard for Mo $(40 \mu \mathrm{g} / \mathrm{L})$ [33]. In Canada, the interim water quality guideline for Mo for the protection of freshwater life is $73 \mu \mathrm{g} / \mathrm{L}$ [34,35]. The Jordanian Standards for (Mo) in drinking water since 2008 is $70 \mu \mathrm{g} / \mathrm{L}[36]$.

The sampled wells exhibit Mo content higher than the Jordanian, WHO, Canadian, and U.S. standards by the order of about 10 times. The origin of Mo enrichment is related to the presence of thick bituminous marl beds in the stratigraphic sequence of the catchment area. The area is characterized by the presence of combusted bituminous marl and unusual highly alkaline circulating waters that continuously liberate reduction sensitive elements [37]. The water/bituminous marl interaction has led to the leaching of Mo from the rock to the groundwater $[17,18]$.

Table 2 shows the geochemical and physical parameters (Eh, $\mathrm{pH}$, and EC values) of the sampled wells. Figure 4 illustrates the Eh vs. pH relationship [38]. The Mo species in the sampled wells are confined to the field of $\mathrm{MoO}_{4}{ }^{2-}$. Therefore, it is evident that the cation exchange sites in the zeolites will not act as a sink to remove Mo. Table 3 gives the concentration of other dissolved ions in Well No 5. For the purpose of this work, the water sample from Well No. 5 was subjected to treatment experiments. 


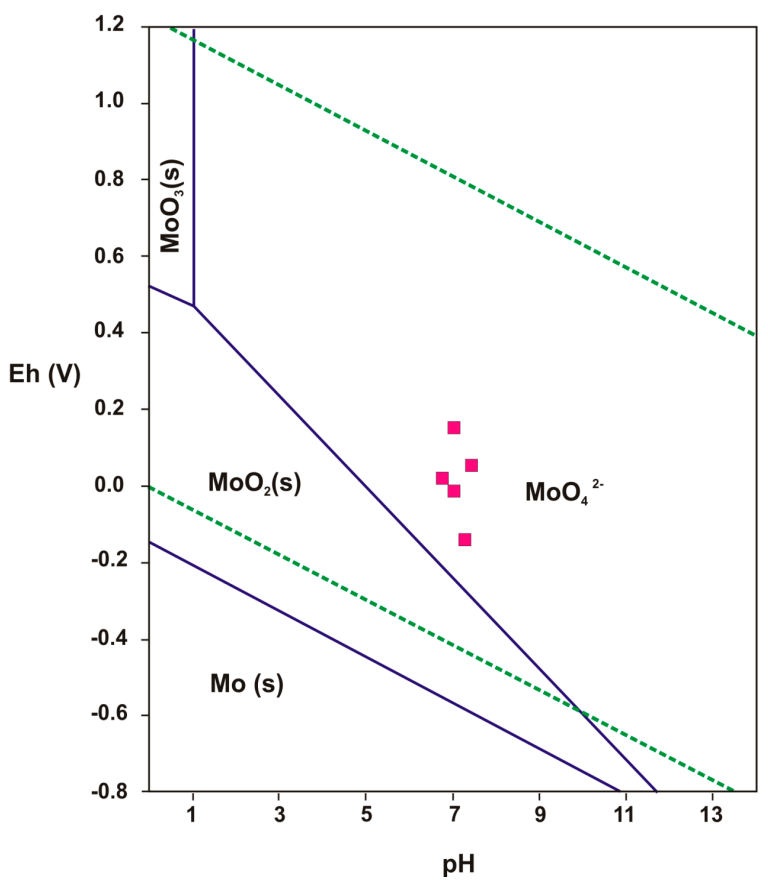

Figure 4. Eh-pH plot of the water samples in the system Mo-O-H. Mo = 10-10 m mole, $298.15 \mathrm{~K}$, $105 \mathrm{~Pa}$ [38].

Table 2. Chemical parameters of the selected groundwater samples.

\begin{tabular}{ccccc}
\hline Well No. & $\mathbf{5}$ & $\mathbf{1 1}$ & $\mathbf{1 2}$ & $\mathbf{1 3}$ \\
\hline Mo Conc. $\mu \mathrm{g} / \mathrm{L}$ & 550 & 790 & 330 & 400 \\
$\mathrm{pH}$ & 7.25 & 7.05 & 7.01 & 6.93 \\
$\mathrm{Eh}(\mathrm{mV})$ & 80 & 140 & -20 & 30 \\
$\mathrm{EC}(\mu \mathrm{S} / \mathrm{cm})$ & 765 & 818 & 805 & 840 \\
Turbidity $(\mathrm{NTU})$ & 0.46 & 0.4 & 0.70 & 0.24 \\
Temperature $^{\circ} \mathrm{C}$ & $26^{\circ}$ & $27.9^{\circ}$ & $27^{\circ}$ & $26^{\circ}$ \\
\hline
\end{tabular}

Table 3. The concentration of the selected dissolved ions in Well No. 5.

\begin{tabular}{cc}
\hline Major Ions & Conc. $(\mathrm{mg} / \mathrm{L})$ \\
\hline $\mathrm{Ca}$ & 103.78 \\
$\mathrm{Mg}$ & 35.65 \\
$\mathrm{Cl}$ & 44.00 \\
$\mathrm{Na}$ & 21.89 \\
$\mathrm{Si}$ & 9.438 \\
\hline Trace Elements & Conc. $(\mu \mathrm{g} / \mathrm{L})$ \\
\hline $\mathrm{Mo}$ & 550 \\
$\mathrm{Sr}$ & 552.42 \\
$\mathrm{Ba}$ & 116.52 \\
$\mathrm{Br}$ & 141 \\
$\mathrm{Ni}$ & 110 \\
\hline
\end{tabular}

\subsection{Batch Experiment Results}

\subsubsection{Efficiency of the Faujasite-Phillipsite Tuff (HN)}

One gram of the HN sample was studied at different contact time versus a fixed volume; and at different volumes versus a fixed contact time. The initial concentration of Mo and Ni in the water sample from water well No. 5 was 0.55 and $0.11 \mathrm{mg} / \mathrm{L}$, respectively. 
Figure 5 represents the efficiency of the HN sample to remove Mo and Ni from $20 \mathrm{~mL}$ of water samples. As the contact time increases, the efficiency removal of Mo and Ni increases. Figure 5 illustrates that the efficiency removal of Mo starts from less than $50 \%$ at $2 \mathrm{~min}$, then increases to about $76.4 \%$ at $120 \mathrm{~min}$ and declines afterward to about $70 \%$ at $360 \mathrm{~min}(6 \mathrm{~h})$. This may indicate that the HN sample has reached equilibrium after $120 \mathrm{~min}$ with the maximum efficiency. Mo present in anionic and not in cationic form in solution may indicate that the mechanism of Mo removal by the zeolites is not cation exchange but rather adsorption at the external surface sites of the zeolite structure. The removal efficiency of Ni varies from about $18 \%$ to about $81.8 \%$ (Figure 5 ).

Figure 6 exhibits the adsorption results of $1 \mathrm{~g}$ HN sample at $2 \mathrm{~h}$ contact time versus different volumes of water samples. In details, the removal efficiency of Mo varies from about $78 \%$ by using $20 \mathrm{~mL}$ increased to about $80 \%$ using $40 \mathrm{~mL}$. At a volume of $120 \mathrm{~mL}$ a drop down to about $76 \%$ was recorded; afterward the removal efficiency became constant at $78 \%$. This indicates that the removal efficiency varies in the range of $\pm 2 \%$ with a change of water volume from 20 to $200 \mathrm{~mL}$. The figure indicates that, regardless of the total amount of molybdates in solution, the sorption capacity of $1 \mathrm{~g}$ of the sorbent remains constant. This means that the removal does not depend on the solid to liquid ratio. The $\pm 2 \%$ is within the experimental error. This result is not well understood and is awaiting further investigation.

As a conclusion, the maximum efficiency of the natural faujasite-phillipsite tuff (HN sample) to remove Mo from the sampled drinking water is $80 \%$, knowing that the initial Mo concentration is $0.55 \mathrm{mg} / \mathrm{L}$. This can be achieved by applying $1 \mathrm{~g}$ of the HN sample to $40 \mathrm{~mL}$ drinking water at $2 \mathrm{~h}$ contact time. Therefore the uptake of Mo from drinking water is $0.44 \mathrm{mg} / \mathrm{L}$ of Mo/g of zeolite after $120 \mathrm{~min}$. The residual Mo content in the treated water is $0.11 \mathrm{mg} / \mathrm{L}$, which is still higher than the permissible limits of $0.07 \mathrm{mg} / \mathrm{L}$ [6].

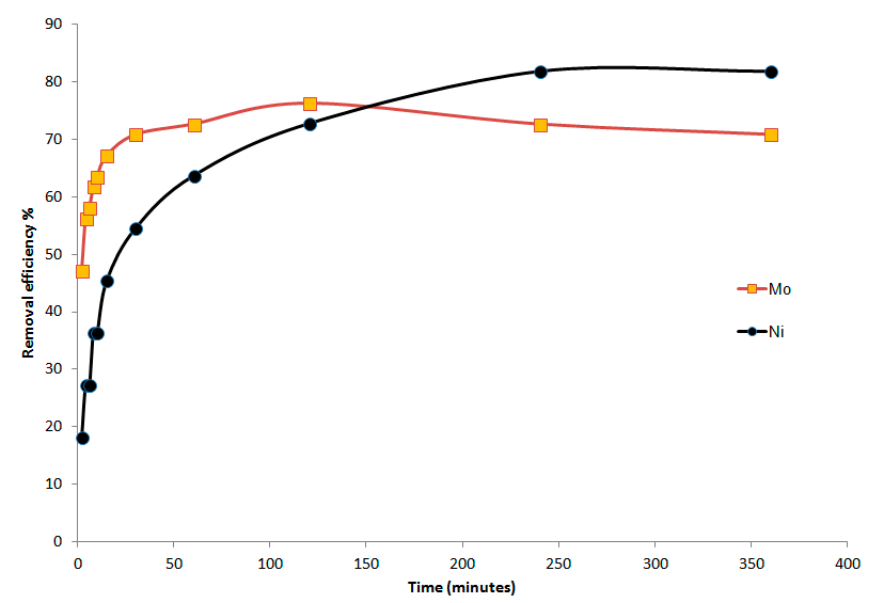

Figure 5. Mo and Ni removal efficiency by the natural faujasite-phillipsite tuff at different contact times.

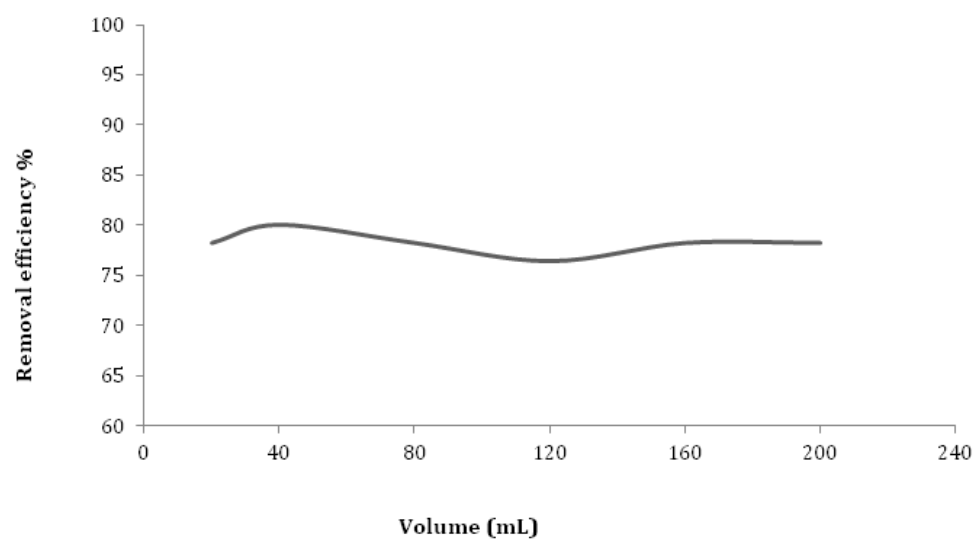

Figure 6. Mo removal efficiency by the natural faujasite-phillipsite tuff at different water volumes. 


\subsubsection{Efficiency of the Phillipsite-Chabazite Tuff}

Similarly, $1 \mathrm{~g}$ of the TM sample was also studied at different contact times versus a fixed volume; and at different volumes versus a fixed contact time. The initial concentration of $\mathrm{Mo}$ and $\mathrm{Ni}$ is the same as in the previous section. Two types of TM samples were studied: surfactant-modified (SMZ) TM and non-modified (NMZ) TM, with the objective of evaluating and comparing their efficiency at removing Mo and Ni from groundwater. The anionic exchange capacity (AEC) of the SMZ is equal to $121 \mathrm{meq} / 100 \mathrm{~g}$ (Table 1 ).

Figure 7 presents the adsorption results of Mo by the SMZ and NMZ using 20-mL water samples. At the beginning with contact time equal to $15 \mathrm{~min}$, the SMZ and the NMZ show higher removal efficiency of Mo from water samples equal to $78 \%$ and $76 \%$, respectively. As the contact time increases, the efficiency removal of Mo decreases to $47 \%$ and $42 \%$, respectively. It is clear from Figure 7 that there is a slight difference in the Mo removal efficiency of the two types of TM samples. The surfactant modification of zeolites reveals a slight enhancement in its removal efficiency between $2 \%$ to $5 \%$. The uptake of the SMZ and NMZ is $0.43 \mathrm{mg} / \mathrm{L} \mathrm{Mo} / \mathrm{g}$ and $0.42 \mathrm{mg} / \mathrm{L} \mathrm{Mo} / \mathrm{g}$, respectively, at $15 \mathrm{~min}$. This means that the residual Mo content in the treated groundwater using the SMZ and NMZ is $0.12 \mathrm{mg} / \mathrm{L}$ and $13 \mathrm{mg} / \mathrm{L}$, respectively, which is about two times higher than the permissible limits of $0.07 \mathrm{mg} / \mathrm{L}$ [6]. This result indicates that zeolite modification is not viable. It would be expected that the removal efficiency of SMZ is much higher than that of NMZ. This is because molybdates are anionic species that can be removed by the SMZ. The explanation can be discussed in the light of the ion selectivity and presence of competing ions in the drinking water, which might occupy the available adsorption sites.

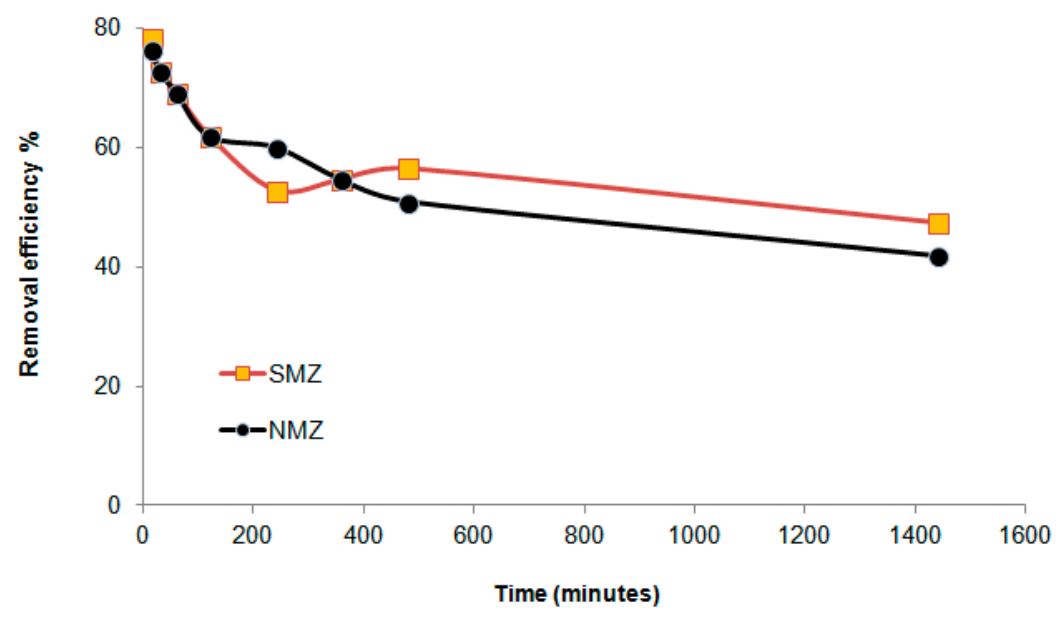

Figure 7. Mo removal efficiency by the surfactant modified and non-modified phillipsite-chabazite tuff as a function of contact time.

Figure 8 illustrates the adsorption results of Ni by using the SMZ and NMZ samples. The proportional relationship between contact time and removal efficiency of $\mathrm{Ni}$ from water samples is evident. It starts with about $9 \%$ for both TM samples at low contact time and increases to $81 \%$ and $91 \%$ after $24 \mathrm{~h}$ using the SMZ and NMZ samples, respectively. The efficiency of the original TM sample in removing Ni is about $10 \%$ higher than the SMZ sample (Figure 8). The removal of Ni by zeolites from solutions is by cation exchange reactions and, due to the large size of the surfactant, some of the zeolites' cation exchange sites might be blocked by the surfactant. This leads to a reduction of the zeolites' ion exchange capacity. This conclusion emphasizes the inefficient zeolite modification by the HDTMA-Br surfactant to enhance their efficiency in freeing groundwater of Mo and Ni. 


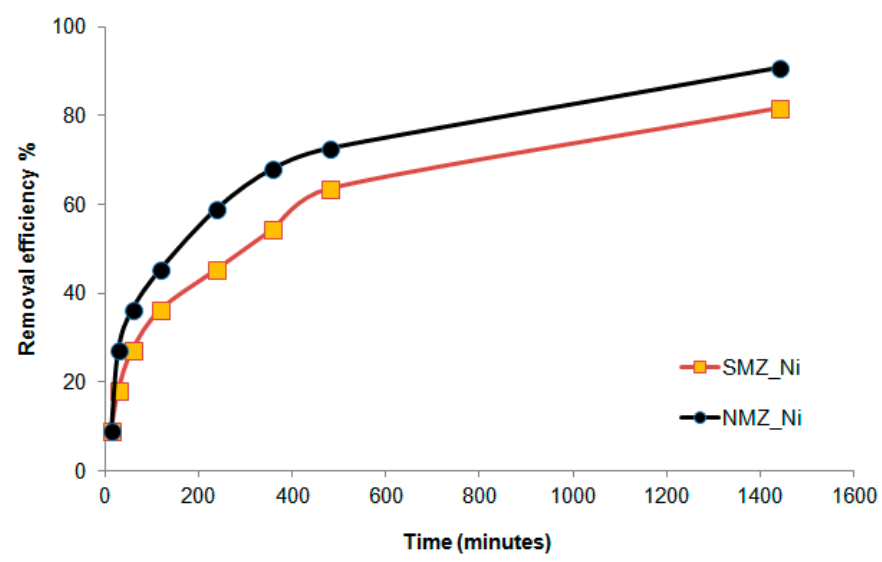

Figure 8. Ni removal efficiency by the surfactant modified and non-modified phillipsite-chabazite tuff as a function of contact time.

Figure 9 exhibits the adsorption results of different weight of SMZ at 15 min contact time using a $40-\mathrm{mL}$ water sample. The removal efficiency of Mo starts with about $80 \%$ using $1 \mathrm{~g}$ of SMZ sample, then declines to about $60 \%$ using $3 \mathrm{~g}$, showing an inverse relationship. This reduction in the removal efficiency may be due to insufficient contact time for the whole SMZ sample to interact with the water sample. The efficiency of SMZ in removing Ni from the water is evident in Figure 9. It varies between $9 \%$ and $79 \%$.

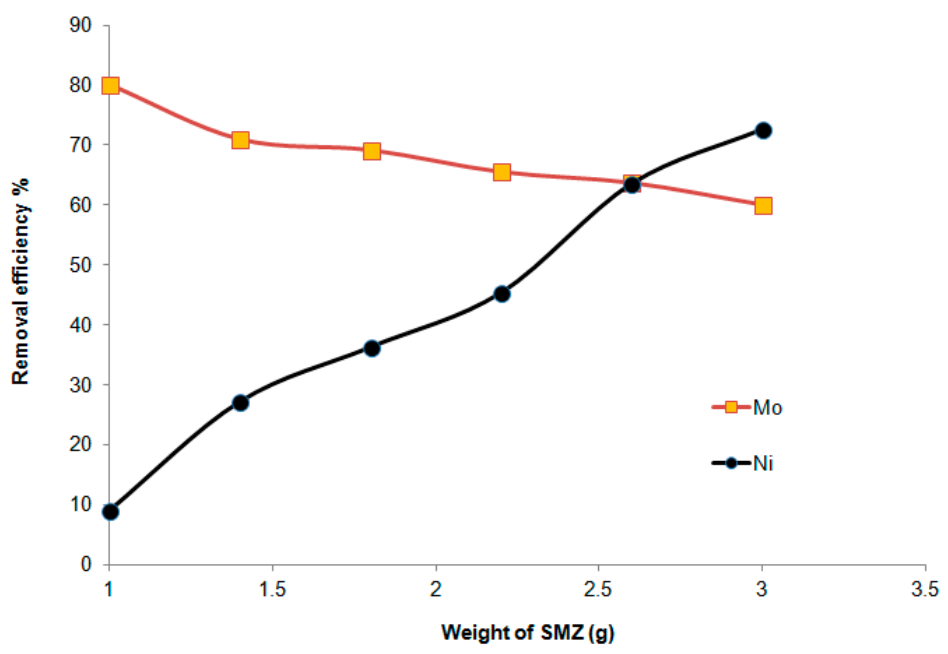

Figure 9. Mo and Ni removal efficiency by the surfactant modified phillipsite-chabazite tuff at different sample weights.

\section{Discussion and Conclusions}

The removal of pollutants from solutions using zeolites is affected by many factors including temperature, solution $\mathrm{pH}$, the presence of competing ions and complexing agents, the dimensions of the hydrated dissolved species compared to the opening of the zeolite channels, and the external surface activity [39]. In addition, the adsorption properties of zeolites are strongly related to the zeolite type, number, and location of their accessible cations, which are the sites for adsorption [40]. The experiments were performed at room temperature $\left(23^{\circ} \mathrm{C}\right)$. The $\mathrm{pH}$ of the starting solution before the addition of the sorbent was 7.25. The $\mathrm{pH}$ of the final solution after the addition of the sorbent increased significantly, most probably due to a release of $\mathrm{Na}, \mathrm{K}, \mathrm{Ca}$, and $\mathrm{Mg}$ from the zeolite structure as a result of cation exchange reactions $[20,25]$. The presence of competing ions in the studied drinking water is evident from Table 3 . The ion exchange selectivity series of zeolites depend on many factors 
including zeolites' type and the strength of the ion in solute. The ion exchange selectivity series of phillipsite and chabazite is: $\mathrm{Na}>\mathrm{Sr} \geq \mathrm{Ca}$ [41]. Zeolites have the following affinity for metals: $\mathrm{Al}^{3+}>\mathrm{Cr}^{2+}>\mathrm{Pb}^{2+}>\mathrm{Ni}^{2+}>\mathrm{Cd}^{2+}>\mathrm{Cu}^{2+}>\mathrm{Zn}^{2+}$ [42]. Hence, sorption of Mo will be severely hindered in the presence of other ions in drinking water samples, as reported by $[15,17]$.

The mechanism of Mo removal by zeolite tuff can be explored in the light of the chemistry of the Mo aquo-species, which is strongly dependent on solution $\mathrm{pH}$ and Eh. Based on the measured $\mathrm{pH}$ and Eh values of the water samples, Mo occurs in a complex anion in the form of $\mathrm{MoO}_{4}{ }^{2-}$ (Figure 2). The cation exchange sites within the zeolite's structure will not be available for the $\mathrm{MoO}_{4}{ }^{2-}$ ions. Thus, the mechanism of Mo removal from the water by zeolites seems to be complex. It might be related to the adsorption reactions at the external surfaces of the zeolites crystals and thus the reduction of the zeolites' efficiency. In this study the two non-modified zeolite samples from Jordan ( $\mathrm{HN}$ and TM) have shown good efficiency in removing molybdate from the studied drinking water by $80 \%$ and $76 \%$, respectively. The natural forms of clinoptilolite-rich tuffs and natrolite from Iranian deposits show negligible uptake of molybdate ions compared with the $\mathrm{Ag}^{1+}, \mathrm{Cd}^{2+}$, and $\mathrm{Pb}^{2+}$ exchanged forms [43]. It was concluded that molybdate could be considerably adsorbed by the exchanged forms. The adsorption ability of Mo ion $\left(\mathrm{Mo}^{6+}\right)$ with zeolite-A type adsorbent could be improved when the counter cation $\left(\mathrm{Na}^{+}\right)$was exchanged by divalent ions $\left(\mathrm{Sr}^{2+}\right.$ and $\left.\mathrm{Ca}^{2+}\right)$ [44]. The adsorption of $\mathrm{Mo}^{6+}$ occurs in the acidic $\mathrm{pH}$ region and the adsorption amount of $\mathrm{Mo}^{6+}$ decreases with an increase in the $\mathrm{pH}[44]$.

In an attempt to overcome the anionic character of the molybdate $\left(\mathrm{MoO}_{4}{ }^{2-}\right)$, a surfactant modified zeolite (SMZ) from the TM sample was used for water treatment experiments. It was concluded that the surfactant modification of the TM zeolites enhances its removal efficiency to become $2 \%$ to $5 \%$ higher than the non-modified TM. The result indicates that modification is not as useful as would be expected. The experiments were made with no control on solution $\mathrm{pH}$; therefore, it is believed that the final $\mathrm{pH}$ became alkaline. Similarly, modification of clinoptilolite by surfactants for molybdate $\left({ }^{99} \mathrm{Mo}\right)$ adsorption from aqueous solution indicated that surfactant modification enhances the zeolite's molybdate adsorption, particularly at $\mathrm{pH}$ values lower than 5.5 [45]. The removal of molybdate anions from water using clinoptilolite zeolite coated with magnetite nanoparticles indicates that at the optimum $\mathrm{pH}$ of 3 , the adsorption capacity is around $18 \mathrm{mg} \mathrm{Mo} / \mathrm{g}$ adsorbent [46].

The maximum removal efficiency of Mo from the sampled groundwater by the studied faujasite-phillipsite and the phillipsite-chabazite and the surfactant modified phillipsite-chabazaite tuffs are $80 \%, 76 \%$, and $78 \%$, respectively. This implies that the rate of Mo removal from drinking water is equivalent to $440-420 \mu \mathrm{g} \cdot \mathrm{Mo} / \mathrm{g}$ adsorbent. The obtained results have indicated that the use of the zeolitic tuff as an adsorbent alone was not enough to reduce the Mo concentration in the drinking water to the permissible level; therefore, extra treatment methods are needed. The proportional relationship between contact time and removal efficiency of $\mathrm{Ni}$ from water samples is evident. The removal efficiency of $\mathrm{Ni}$ from the sampled groundwater increases to $81 \%$ and $91 \%$ after $24 \mathrm{~h}$ using the studied zeolitic tuff samples.

Acknowledgments: The authors would like to thank Hamdi Mango Center for Scientific Research (University of Jordan) for their financial support of the project entitled "Characterization and beneficiation of new-explored Jordanian zeolitic tuff from selected localities in northern, central, and southern Jordan, and investigation their capability for removal of pollutants from water". Special thanks are given to N. El-Banna, K. Shwayat and S. Abu-Alhaijaa from the Laboratories and Quality Affairs/Water Authority of Jordan, who were involved in collecting the samples and performing the analysis. Thanks are also extended to the reviewers of this article for their critical comments and suggestions.

Author Contributions: Khalil Ibrahim and Hani Khoury conceived and designed the experiments; Khalil Ibrahim and Hani Khoury performed the experiments; Khalil Ibrahim analyzed the data; Randa Tuffaha contributed reagents/materials/analysis tools; Khalil Ibrahim wrote the paper.

Conflicts of Interest: The authors declare no conflict of interest. 


\section{References}

1. Mielke, J.E. Composition of the Earth's crust and distribution of the elements. In Review of Research on Modern Problems in Geochemistry; Siegel, F.R., Ed.; UNESCO Report; The United Nations Educational, Scientific and Cultural Organization (UNESCO): Paris, France, 1979; pp. 13-37.

2. Wedepohl, K.H. The composition of the crust. Geochim. Cosmochim. Acta 1995, 59, 1217-1232. [CrossRef]

3. Kuroda, P.K.; Sandell, E.B. Geochemistry of molybdenum. Geochim. Cosmoch. Acta 1954, 6, 35-63. [CrossRef]

4. Scientific Committee on Food (SCF). Opinion of the Scientific Committee on Food on the Tolerable upper Intake Level of Molybdenum. SCF/CS/NUT/UPPLEV/22 Final. 2000. Available online: http:/ /ec.europa. eu/food/fs/sc/scf/out80h_en.pdf (accessed on 19 July 2016).

5. Wang, D. Redox chemistry of molybdenum in natural waters and its involvement in biological evolution. Front. Microbiol. 2012, 3, 427. [CrossRef] [PubMed]

6. World Health Organization (WHO). Molybdenum in Drinking-Water: Background Document for Development of WHO Guidelines for Drinking-Water Quality. WHO/SDE/WSH/03.04/11/Rev/1. 2011. Available online: http://www.who.int/water_sanitation_health/dwq/chemicals/molybdenum.pdf (accessed on 19 July 2016).

7. Kabata-Pendias, A.; Mukherjee, A.B. Trace Elements from Soil to Human; Springer-Verlag: Berlin, Germany, 2007; pp. 39-45.

8. Das, A.K.; Chakraborty, R.; Cervera, M.L.; de la Guardia, M. A review on molybdenum determination in solid geological samples. Talanta 2007, 71, 987-1000. [CrossRef] [PubMed]

9. Valle, T.I. Geochemistry of molybdenum in the Aquia Aquifer, Maryland, USA. Master's Thesis, Faculty of the Graduate School, The University Texas at Arlington, Arlington, TX, USA, 2009.

10. Brookins, D.G. Eh-pH Diagrams for Geochemistry; Spring-Verlag: New York, NY, USA, 1988; p. 176.

11. Ure, A.M.; Berrow, M.L. The chemical constituents of soils. In Environmental Chemistry; Bowen, H.J.M., Ed.; Royal Society of Chemistry, Burlington House: London, UK, 1982; pp. 94-202.

12. McGrath, S.P. Chromium and nickel. In Heavy Metals in Soil; Alloway, B.J., Ed.; Chapman and Hall: London, UK, 1995; pp. 139-155.

13. Koppelman, M.H.; Dillard, J.G. A study of the adsorption of $\mathrm{Ni}(\mathrm{II})$ and $\mathrm{Cu}(\mathrm{II})$ by clay minerals. Clays Clay Miner. 1977, 25, 457-462. [CrossRef]

14. World Health Organization (WHO). Chapter 6.10 Nickel. In Air Quality Guidelines for Europe, 2nd ed.; European Series No. 91; WHO Regional Publications: Copenhagen, Denmark, 2000.

15. Abu Al Rous, M.N. Investigation and a Reconnaissance Survey of Molybdenum (Mo) Concentrations in Groundwater Used for Drinking Water in Wadi El Arab Area, Northern Jordan. Master's Thesis, Hashemite University, Zarqa, Jordan, 2013.

16. Al Kuisi, M.; Al-Hwaiti, M.; Mashal, K.; Abed, A.M. Spatial distribution patterns of molybdenum (Mo) concentrations in potable groundwater in Northern Jordan. Environ. Monit. Assess. 2015. [CrossRef] [PubMed]

17. El-Naqa, A.R.; Ibrahim, K.M.; Abu Alrous, M. A preliminary survey of molybdenum (Mo) in groundwater used as potable water in Wadi Al Arab Catchment area, Northern Jordan. Manuscript in preparation.

18. Misaelides, P. Application of natural zeolites in environmental remediation: A short review. Microporous Mesoporous Mater. 2011, 144, 15-18. [CrossRef]

19. Bowman, R.S. Applications of surfactant-modified zeolites to environmental remediation. Microporous Mesoporous Mater. 2003, 61, 43-56. [CrossRef]

20. Ibrahim, K.M. Geology, Mineralogy, Chemistry, Origin and Uses of the Zeolites Associated with Quaternary Tuffs of North East Jordan. Ph.D. Thesis, Royal Holloway, University of London, Egham, UK, 1996.

21. Ibrahim, K.; Jbara, H. Removal of paraquat from synthetic wastewater using phillipsite-faujasite tuff from Jordan. J. Hazard. Mater. 2009, 163, 82-86. [CrossRef] [PubMed]

22. Rawajfih, Z.; Al Mohammad, H.; Nsour, N.; Ibrahim, K. Study of equilibrium and thermodynamic adsorption of $\alpha$-picoline, $\beta$-picoline, and $\gamma$-picoline by Jordanian zeolites: Phillipsite and faujasite. Microporous Mesoporous Mater. 2010, 132, 401-408. [CrossRef]

23. Al Dwairi, R.; Ibrahim, K.M.; Khoury, H.N. Potential use of faujasite-phillipsite and phillipsite-chabazite tuff in purification of treated effluent from domestic wastewater treatment plants. Environ. Earth Sci. 2014, 71, 5071-5078. [CrossRef] 
24. Hussein, M.M.; Khader, K.M.; Musleh, S.M. Characterization of raw zeolite and surfactant-modified zeolite and their use in removal of selected organic pollutants from water. Int. J. Chem. Sci. 2014, 12, 815-884.

25. Al-Haj-Ali, A.; Marashdeh, L.M. Removal of aqueous chromium (III) ions using Jordanian natural zeolite tuff in batch and fixed bed modes. Jordan J. Earth Environ. Sci. 2014, 6, 45-51.

26. Ibrahim, K.M.; Nasser Ed-Deen, T.; Khoury, H. Use of natural chabazite-phillipsite tuff in wastewater treatment from electroplating factories in Jordan. Environ. Geol. 2002, 41, 547-551. [CrossRef]

27. Shammout, N. Removal of Selected Heavy Metals Using Jordanian Zeolites. Master's Thesis, University of Jordan, Amman, Jordan, 1993.

28. Shaheen, S.M.; Derbalah, A.S.; Moghanm, F.S. Removal of heavy metals from aqueous solution by zeolite in competitive sorption system. Int. J. Environ. Sci. Dev. 2012, 3, 362-367. [CrossRef]

29. Kitsopoulos, K.P. Cation-exchange capacity (CEC) of zeolitic volcaniclastic materials: Applicability of the ammonium acetate saturation (AMAS) method. Clays Clay Miner. 1999, 47, 688-696. [CrossRef]

30. Li, Z.; Burt, T.; Bowman, R.S. Sorption of ionizable organic eolutes by surfactant-modified zeolite. Environ. Sci. Technol. 2000, 43, 3756-3760. [CrossRef]

31. Rice, E.W.; Baird, R.B.; Eaton, A.D.; Clesceri, L.S. Standard Methods for the Examination of Water and Wastewater; American Water Works Association and Water Environment Federation: New York, NY, USA, 2012.

32. Diale, P.P.; Muzenda, E.; Zimba, J. A study of South African natural zeolites properties and applications. In Proceedings of the World Congress on Engineering and Computer Science 2 WCECS 2011, San Francisco, CA, USA, 19-21 October 2011.

33. Wisconsin Department of Health. Molybdenum in Drinking Water, Public Health Service, U.S. Department of Health and Human Services P-00150 (Rev. 08/2013). Available online: https:/ /www.dhs.wisconsin.gov/ publications/p0/p00150.pdf (accessed on 19 July 2016).

34. Fletcher, T.; Stephenson, G.L.; Muncaster, B.; Wren, C.D.; Spry, D.J. Scientific Criteria Document for the Development of an Interim Provincial Water Quality Objective for Molybdenum; Ontario Ministry of Environment and Energy, Standard Development Branch: Toronto, ON, Canada, 1997.

35. Canadian Council of Ministers of the Environment. Molybdenum, Canadian Water Quality Guidelines for the Protection of Aquatic Life: CCME Water Quality Index 1.0, User's Manual. Canadian Environmental Quality Guidelines. 1999. Available online: http:/ /ceqg-rcqe.ccme.ca/download/en/195 (accessed on 19 July 2016).

36. Jordanian Standards 286. Jordanian Standards for Drinking Water. 2008. Available online: http:/ /ocid.nacse. org/rewab/docs/JS286_Drinking_Water_2008_ar.pdf (accessed on 17 September 2016).

37. Abdul-Jaber, Q.; Khoury, H.N. Unusual mineralization in the Maqarin area (north Jordan) and the occurrence of some rare minerals in the marbles and the weathered rocks. N. Jahrb. Geol. Palaeontol. Abh. 1998, 208, 603-629.

38. National Institute of Advanced Industrial Science and Technology. Atlas of Eh-pH Diagrams Intercomparison of Thermodynamic Databases; Geological Survey of Japan Open File Report No. 419; National Institute of Advanced Industrial Science and Technology: Tokyo, Japan, 2005.

39. Colella, C. Recent Advances in Natural Zeolite Applications Based on External Surface Interaction with Cations and Moleculs. Stud. Surf. Sci. Catal. 2007, 170, 2063-2073.

40. Arbuznikov, A.; Vasilyev, V.; Goursot, A. Relationships between the structure of a zeolite and its adsorption properties. Surf. Sci. 1998, 397, 395-405. [CrossRef]

41. Ames, L. Zeolite cation selectivity. Can. Miner. 1965, 8, 325-333.

42. Ziyath, A.M.M. Removal of Toxic Metals in Multi Metal System Using Sorbents for Potential Application to Urban Stormwater Treatment. Ph.D. Thesis, Queensland University of Technology, Brisbane, Australia, 2012.

43. Faghihian, H.; Malekpour, A.; Maragheh, M.G. Adsorption of molybdate ion by natrolite and clinoptilolite-rich tuffs. J. Environ. Pollut. 2002, 18, 181-189. [CrossRef]

44. Nishihama, S.; Yoshizuka, K. Ion exchange adsorption of molybdenum with zeolitic adsorbent. J. Environ. Eng. Manag. 2009, 19, 365-369. 
45. Faghihian, H.; Malekpour, A.; Maragheh, M.G. Modification of clinoptilolite by surfactants for molybdate $\left({ }^{99} \mathrm{Mo}\right)$ adsorption from aqueous solutions. J. Sci. Islam. Repub. Iran 2003, 14, 239-245.

46. Verbinnen, B.; Block, C.; Hannes, D.; Lievens, P.; Vaclavikova, M.; Stefusova, K.; Gallios, G.; Vandecasteele, C. Removal of molybdate anions from water by adsorption on zeolite-supported magnetite. Water Environ. Res. 2012, 84, 753-760. [CrossRef] [PubMed] article distributed under the terms and conditions of the Creative Commons Attribution (CC-BY) license (http://creativecommons.org/licenses/by/4.0/). 